\title{
Pelaksanaan Manajemen Klinis di Instalasi Gawat Darurat di RS Siaga Raya Pada Masa Pandemi COVID-19
}

\author{
RM Affandi Akbar, Lili Indrawati , Sumijatun \\ Universitas Respati Indonesia \\ Email : affandi_akbar@yahoo.com
}

\begin{abstract}
ABSTRAK
Coronavirus-19 telah dinyatakan sebagai pandemi dunia oleh WHO. Pada 22 Februari 2021, WHO melaporkan 111.102.016 kasus dengan 2.462.911 kematian di seluruh dunia dan Kementerian Kesehatan melaporkan 1.288.833 kasus di Indonesia dengan 34.691 kematian serta Pemerintah provinsi DKI Jakarta melaporkan 331.094 kasus di Jakarta dengan 5.206 kematian. Pemerintah telah menetapkan Keputusan Presiden Nomor 11 Tahun 2020 tentang Penetapan Kedaruratan Kesehatan Masyarakat COVID-19. Rumah sakit diharapkan dapat mengikuti manajemen klinis sesuai dengan pedoman COVID-19 bagi petugas kesehatan dan seluruh penduduk Indonesia agar mendapatkan pelayanan yang sesuai standar. Tujuan penelitian adalah mengetahui pelaksanaan, evaluasi serta hal yang menghambat manajemen klinis di IGD di RS Siaga Raya pada masa pandemi COVID-19. Menggunakan metode kualitatif. teknik pengumpulan data dilakukan tringulasi, bersifat induktif, dan hasil penelitian lebih menekankan makna daripada generalisasi. IGD RS Siaga Raya pada masa pandemi COVID-19 telah melakukan skrining pada dengan dilakukannya pemeriksaan suhu, saturasi oksigen dan pertanyaan singkat, apabila ditemukan indikasi COVID-19, pasien langsung diarahkan ke rumah sakit rujukan, dan bila ada pasien yang akan direncanakan rawat inap, pasien dilakukan pemeriksaan PCR dan Laboratorium . Evaluasi dan monitoring manajemen klinis COVID-19 belum dilakukan. Terdapat hambatan terkait pelaksanaan alur manajemen klinis dan SOP yang masih belum ada, serta keterbatasan ruangan IGD.Diharapkan IGD RS Siaga Raya dapat selalu mengembangkan serta menyediakan SOP terkait manajemen klinis COVID-19, dan menyediakan ruangan khusus COVID serta peneliti selanjutnya dapat mengkomparasikan dengan penelitian di RS lain dan disertakan informan ahli.

Kata kunci: COVID-19, Manajemen Klinis, Pandemi, Instalasi Gawat Darurat.
\end{abstract}

\begin{abstract}
Coronavirus-19 has been declared a world pandemic by WHO. On February 22, 2021, WHO reported 111,102,016 cases with 2,462,911 deaths worldwide and the Ministry of Health reported 1,288,833 cases in Indonesia with 34,691 deaths and the DKI Jakarta provincial government reported 331,094 cases in Jakarta with 5,206 deaths. The government has issued Presidential Decree No.11 of 2020 concerning the Determination of Public Health Emergencies for COVID-19. Hospitals are expected to be able to follow clinical management in accordance with COVID-19 guidelines for health workers and all Indonesian residents to get services that are according to standards. The aim of the research was to find out the implementation, evaluation and things that hindered clinical management in the emergency room at the Siaga Raya Hospital during the COVID-19 pandemic. Using qualitative methods. The data collection technique is tringulation, inductive in nature, and the results of the research emphasize meaning rather than generalization. The emergency department of Siaga Raya Hospital during the COVID-19 pandemic has carried out a screening by checking temperature, oxygen saturation and short questions, if an indication of COVID-19 is found, the patient is immediately directed to a referral hospital, and if there are patients who will be hospitalized, the patient was subjected to PCR and laboratory examinations. Evaluation and monitoring of the clinical management of COVID-19 has not been carried out. There are obstacles related to the implementation of clinical management flow and SOPs that do not yet exist, as well as limited emergency room rooms.

Keyword: Keywords: COVID-19, Clinical Management, Pandemic, Emergency Room.
\end{abstract}




\section{PENDAHULUAN}

Coronavirus-19 (COVID) telah dinyatakan sebagai pandemi dunia oleh WHO (WHO,2020). Coronavirus adalah zoonosis atau virus yang ditularkan antara hewan dan manusia. Virus dan penyakit ini diketahui berawal di kota Wuhan, Cina sejak Desember 2019. Per tanggal 21 Maret 2020. Gugus tugas percepatan penanganan COVID-19 melaporkan jumlah kasus penyakit ini mencapai angka 275,469 jiwa yang tersebar di 166 negara, termasuk Indonesia. Sampai dengan tanggal 22 Februari 2021, WHO melaporkan 111.102.016 kasus konfirmasi dengan 2.462.911 kematian di seluruh dunia (Case Fatality Rate/CFR 2,21\%) dan Kementerian Kesehatan melaporkan 1.288.833 kasus konfirmasi COVID-19 di Indonesia dengan 34.691 kasus meninggal (CFR 2,69\%) dan Pemerintah provinsi DKI Jakarta melaporkan 331.094 kasus terkonfirmasi COVID-19 di Jakarta dengan 5.206 kasus meninggal (CFR $1.57 \%$ ).

Presiden Republik Indonesia telah menyatakan status penyakit ini menjadi tahap Tanggap Darurat pada tanggal 17 Maret 2020. Dilihat dari situasi penyebaran COVID-19 yang sudah hampir menjangkau seluruh wilayah provinsi di Indonesia dengan jumlah kasus dan/atau jumlah kematian semakin meningkat, Pemerintah Indonesia telah menetapkan Keputusan Presiden Nomor 11 Tahun 2020 tentang Penetapan Kedaruratan Kesehatan Masyarakat Corona Virus Disease 2019 (COVID-19). Selain itu, atas pertimbangan penyebaran COVID-19 berdampak pada meningkatnya jumlah korban dan kerugian harta benda, meluasnya cakupan wilayah terdampak, serta menimbulkan implikasi pada aspek sosial ekonomi yang luas di Indonesia, telah dikeluarkan juga Keputusan Presiden Nomor 12 Tahun 2020 tentang Penetapan Bencana Nonalam Penyebaran
Corona Virus Disease 2019 (COVID-19) Sebagai Bencana Nasional.

Unit Gawat Darurat merupakan unit pelayanan rumah sakit yang memberikan pelayanan pada pasien yang membutuhkan tindakan medis segera, guna penyelamatan nyawa dan pencegahan kecacatan lebih lanjut. Pelayanan kegawatdaruratan memerlukan penanganan secara terpadu dari multi disiplin multi profesi, dan terintegrasi, dengan struktur organisasi fungsional, yang terdiri dari unsur pimpinan dan unsur pelaksana, yang bertanggung jawab dalam pelaksanaan pelayanan tehadap pasien gawat darurat, dengan wewenang penuh yang dipimpin oleh dokter.

Rumah sakit merupakan institusi pelayanan yang menyelenggarakan upaya pelayanan kesehatan perorangan secara paripurna (promotif, preventif, kuratif dan rehabilitatif) yang menyediakan pelayanan rawat jalan rawat inap dan gawat darurat ( UU No 44 tahun 2009 tentang Rumah Sakit) Dalam menyelenggarakan pelayanan kesehatan, rumah sakit diwajibkan memberikan pelayanan yang aman, bermutu dan efektif sesuai dengan standar pelayanan rumah sakit. Menurut UU Nomor 44 Tahun 2009 Rumah Sakit mempunyai fungsi sebagai berikut, penyelenggaraan pelayanan pengobatan dan pemulihan kesehatan sesuai dengan standar pelayanan rumah sakit; pemeliharaan dan peningkatan kesehatan perorangan melalui pelayanan kesehatan yang paripurna tingkat kedua dan ketiga sesuai kebutuhan medis, penyelenggaraan pendidikan dan pelatihan sumber daya manusia dalam rangka peningkatan kemampuan dalam pemberian pelayanan kesehatan; dan penyelenggaraan penelitian dan pengembangan serta penapisan teknologi bidang kesehatan dalam rangka peningkatan pelayanan kesehatan dengan memperhatikan etika ilmu pengetahuan bidang kesehatan.

Rumah Sakit sebagai salah satu fasilitas pelayanan kesehatan merupakan bagian dari 
sumber daya kesehatan yang sangat diperlukan dalam mendukung penyelenggaraan upaya kesehatan. Penyelenggaran pelayanan kesehatan di Rumah Sakit mempunyai karakteristik dan organisasi yang sangat kompleks. Berbagai jenis tenaga kesehatan dengan perangkat keilmuannya masing-masing berinteraksi satu sama lain. Ilmu pengetahuan dan teknologi kedokteran yang berkembang sangat pesat yang harus diikuti oleh tenaga kesehatan dalam rangka pemberian pelayanan yang bermutu, membuat semakin kompleksnya permasalahan dalam Rumah Sakit. Setiap tenaga kesehatan yang bekerja di RS harus sesuai dengan standar profesi, standar pelayanan RS, standar prosedur operasional yang berlaku, etika profesi, menghormati hak pasien dan mengutamakan keselamatan pasien (UU Nomor 44 tahun 2009, pasal 13), sementara kondisi yang ada di RS, padat karya, padat SDM, padat tehnologi, dan prosedur, yang memungkinkan terjadinya over crowding, kesalahan/ eror, dan kejadian tidak diharapkan (KTD).

Oleh karenanya rumah sakit diharapkan dapat mengikuti manajemen klinis sesuai dengan pedoman pencegahan dan pengendalian COVID-19 yang telah disusun pemerintah berdasarkan rekomendasi WHO yang disesuaikan dengan perkembangan pandemi COVID-19, dan ketentuan peraturan perundang-undangan yang berlaku dalam pelayanan kesehatan sebagai upaya pencegahan dan pengendalian COVID-19 bagi petugas kesehatan dan seluruh penduduk Indonesia agar mendapatkan pelayanan yang sesuai standar.

Sehingga Rumah Sakit Siaga Raya diharapkan dapat melaksanakan manajemen klinis sesuai dengan arahan dari pemerintah berdasarkan pedoman yang ada disertai evaluasi manajemen klinis berkala sebagai upaya untuk terus meningkatkan kualitas manajemen klinis yang sudah berjalan dan melindungi petugas kesehatan agar tetap sehat, aman, dan produktif dan pasien yang berobat mendapat pelayanan yang maksimal sesuai dengan klinisnya.

\section{METODE}

Peneliti menggunakan pendekatan kualitatif dengan menerapkan proses induksi. Adapun jenis penelitian dalam penelitian ini ialah jenis penelitian Case Study Research atau Studi Kasus. Informan dalam penelitian ini yaitu direktur utama, direktur pelayanan medik, kepala IGD, dokter umum, perawat, dan 5 pasien IGD RS Siaga Raya. Teknik analisis data dalam penelitian ini meliputi reduksi data, penyajian data dan penarikan kesimpulan.

\section{HASIL}

1. Pelaksanaan manajemen klinis di IGD RS Siaga Raya pada masa pandemi COVID-19 telah melakukan skrining pada saat ada pasien yang berobat dengan dilakukannya pemeriksaan suhu menggunakan thermo gun, pemeriksaan saturasi oksigen menggunakan pulse oxymetry dan dilakukan pertanyaan singkat seperti menanyakan keluhan demam, riwayat demam, batuk, pilek, nyeri telan, sesak, gangguan penciuman, serta riwayat kontak erat dengan pasien COVID-19, dan apabila ditemukan indikasi mengarah pada gejala klinis pasien COVID-19 pasien langsung diarahkan ke rumah sakit yang dapat menangani COVID-19, pada pasien yang tidak ada gejala klinis tersebut dan akan direncanakan rawat inap, pasien lebih dahulu dilakukan pemeriksaan PCR dan Laboratorium seperti darah perifer lengkap, albumin, SGOT SGPT, ureum, creatinin, $\mathrm{CRP}$, dan rontgen thorax.

2. Evaluasi dan monitoring manajemen klinis di IGD RS Siaga Raya pada masa pandemi COVID-19 belum dilakukan, namun tetap adanya bentuk laporan ke dinkes dikarenakan RS Siaga Raya tidak merawat pasien COVID-19.

3. Hambatan dalam pelaksanaan manajemen klinis pada masa pandemi COVID-19 yaitu terkait pelaksanaan alur manajemen klinis dan SOP terkait yang masih belum dibuat, serta keterbatasan ruangan instalasi gawat darurat, sehingga menghambat pelaksanaan manajemen klinis pada masa pandemi COVID-19 yang diharapkan dapat berjalan maksimal. 
Pelaksanaan Manajemen Klinis di IGD Pada Masa Pandemi COVID-19 Yang Sudah Dilakukan di RS Siaga Raya

Berdasarkan hasil wawancara bahwa pelaksanaan manajemen klinis di Rumah Sakit Siaga Raya sudah berjalan tetapi belum efektif atau optimal. Hal ini dapat dilihat dari tanggapan tenaga medis dan pasien yang mengatakan bahwa kurang begitu mengerti mengenai manajemen klinis khususnya pada masa pandemi COVID-19 dan jika melihat aktifitas di IGD RS Siaga Raya manajemen klinis belum berjalan secara maksimal.

Rumah Sakit Siaga Raya telah berupaya melakukan manajemen klinis pada masa pandemi COVID-19. Manajemen klinis yang dilakukan berupa triage pasien yang datang dengan pemeriksaan suhu dan melakukan pertanyaan singkat yang mengarah pada gejala COVID-19, serta melakukan pemeriksaan lanjutan seperti swab antigen atau PCR apabila pasien akan rawat inap.

Berdasarkan dari hasil wawancara, pelaksanaan manajemen klinis memang sudah berjalan tetapi belum efektif atau optimal. Hal ini dapat diketahui dari informasi yang diberikan Informan dan pasien Rumah Sakit Siaga Raya.

Manajemen klinis di IGD rumah sakit Siaga Raya selama ini berjalan sesuai dengan keputusan menteri kesehatan mengenai standar instalasi gawat darurat yang meliputi kemampuan wajib pelayanan gawat darurat, klasifikasi pelayanan igd, alur pelayanan instalasi gawat darurat, sarana prasaranan instalasi gawat darurat, serta sumber daya manusia di instalasi gawat darurat, kemudan manajemen klinis tersebut diimprovisasi dengan adanya pandemi COVID-19 ini berdasarkan pedoman pencegahan dan pengendalian COVID-19.

Sesuai dengan hasil wawancara Rumah Sakit Siaga Raya sudah menerapkan skrining pasien yang datang sudah berjalan dengan cukup baik, hal ini dapat dilihat dari pendapat narasumber dan beberapa pasien Rumah Sakit, yang menilai manajemen klinis yang dilaksanakan sudah berjalan namun belum maksimal sehingga perlu dikembangkan lagi.

Manajemen Klinis di IGD Rumah Sakit Siaga Raya telah dilakukannya pemeriksaan suhu menggunakan thermal gun dan mengajukan pertanyaan singkat yang mengarah ke gejala klinis COVID-19 sebelum masuk ke IGD . Hal tersebut sesuai dengan pedoman pencegahan dan pengendalian COVID-19 Rev.5 (2020) bahwa pelaksanaan skrining harus dilakukan pada kontak pertama pasien dengan fasyankes termasuk IGD.

Sesuai dengan hasil wawancara dijelaskan bahwa pelaksanaan manajemen klinis dilakukan Rumah Sakit Siaga Raya dapat dikatakan baik meski ada beberapa kelemahan. Setelah dilakukan skrining awal, pasien dengan kecurigaan COVID-19 langsung diarahkan ke rumah sakit rujukan COVID-19 atau fasilitas kesehatan lanjut sesuai dengan kebutuhan pasien. Sesuai dengan pedoman pencegahan dan pengendalian corona virus disease (COVID-

19) rev.5 setelah skrining pasien pada triase dengan dugaan COVID-19 dilakukan evaluasi pasien untuk menentukan tingkat keparahan penyakit. Setelah penilaian awal, manajemen dan stabilisasi, pasien diarahkan ke tujuan perawatan COVID-19 yang sesuai, yaitu di dalam fasyankes (unit perawatan kritis atau bangsal), atau dirujuk ke fasyankes yang berbeda, fasilitas komunitas atau rumah, sesuai dengan kebutuhan medis pasien.

Namun berdasarkan hasil wawancara dan pengamatan penulis belum adanya ruangan khusus di IGD yang membedakan antara pasien curiga COVID-19 dengan pasien tanpa COVID-19, semua pasien yang datang ke Rumah Sakit Siaga Raya ditangani di ruangan yang sama walaupun memiliki gejala klinis curiga COVID-19. Hal ini berarti dapat meningkatkan resiko penyebaran COVID-19 dari pasien curiga COVID-19 kepada pasien tanpa COVID-19 yang seharusnya berdasarkan panduan teknis pelayanan rumah sakit pada masa adaptasi kebiasaan baru ruangan di instalasi gawat darurat dibedakan menjadi ruangan atau zona khusus pasien tanpa gejala COVID-19 
dan ruangan atau zona khusus pasien dengan gejala COVID-19

Dari hasil wawancara dan observasi juga dapat disimpulkan bahwa pelaksanaan manajemen klinis yang sudah berjalan di Rumah Sakit Siaga Raya dapat dikatakan belum masimal. Terlihat pada penggunaan alat kesehatan yang digunakan pada pasien RS Siaga Raya seperti EKG, Stetoskop, Termometer dan lainnya tidak dibedakan pada pasien dengan gejala klinis COVID-19 dan tanpa gejala klinis COVID-19.

Dari hasil wawancara dan observasi dapat dijelaskan bahwa pelaksanaan manajemen klinis oleh Rumah Sakit sudah baik. Mulai dari proses penerimaan pasien awal sampai dengan proses selesai pemberian pelayanan kesehatan dilakukan dengan cepat, tepat, dan hati - hati sehingga tenaga kesehatan merasa aman dan dapat bekerja secara maksimal di rumah sakit sehingga pasien mendapat pelayanan yang baik, dan tepat sesuai klinis Berdasarkan hasil wawancara dan observasi dapat dijelaskan bahwa kemampuan karyawan memberikan pelayanan sesuai dengan apa yang dijanjikan secara akurat dan terpercaya. Walaupun berjalannya manajemen klinis yang belum maksimal, Kemampuan untuk membantu pelanggan memberikan jasa dengan cepat dan tepat. Serta memberikan perhatian yang tulus dan bersifat individual atau pribadi yang diberikan kepada pelanggan

Berdasarkan hasil observasi alat kesehatan yang ada di IGD Rumah Sakit Siaga Raya cukup memadai. Pulse Oxymetri, Thermo Gun, serta alat pelindung diri yang digunakan saat di IGD berupa masker bedah, pembatas kaca antara pasien dan tenaga kesehatan, masker KN95, haircap, faceshield dan baju gown, sesuai dengan hasil observasi, pasien dan keluarga terlihat nyaman dengan alat kesehatan yang digunakan tresebut. Penggunaan alat kesehatan yang digunakan Rumah Sakit Siaga Raya sudah sesuai dengan Pedoman pencegahan dan pengendalian Coronavirus Disease (COVID-19) Rev.5 dan penggunaan rasional APD dari WHO bahwa dalam melakukan skrining dapat menggunakan Thermo Gun dan menggunakan APD berupa masker dan pelindung mata serta pembatas kaca / plastik sebagai penghalang antara tenaga nedis dan pasien.

Dalam menjalankan manajemen klinis di IGD pada masa pandemi COVID-19 Rumah Sakit Siaga Raya selama ini menghadapi beberapa kendala. Kendala tersebut berasal dari keterbatasan ruangan IGD dikarenakan lahan rumah sakit yang sempit dan belum ada rnecana untuk renovasi serta memperluas area IGD dan SOP yang belum dibuat oleh manajemen karena Rumah Sakit Siaga Raya bukan rujukan COVID-19 sehingga manajemen belum ada rencana untuk fokus terhadap SOP terkait COVID19.

Dalam rangka menjalankan manajemen klinis pada masa pandemi COVID-19 untuk melindungi tenaga medis yang bekerja serta pasien yang berobat Rumah Sakit Siaga Raya sudah menjalankan berbagai langkah untuk menghadapi tantangan dan hambatan. Rumah sakit kedepannya akan mengembangkan manajemen klinis yang sudah ada sesuai dengan pedoman terbaru.

Alat kesehatan dan pelindung diri merupakan bagian dari manajemen klinis yang memiliki peranan cukup penting. Pelaksanaan manajemen klinis yang baik diperlukan alat kesehatan dan pelindung diri yang baik pula karena secara nyata turut mempengaruhi keputusan tim triase di lapangan.

Rumah Sakit Siaga Raya belum melakukan pengawasan dan evaluasi terhadap pelaksanaan manajemen klinis. Pengawasan dan evaluasi belum dilakukan dikarenakan belum ada SOP yang jelas dari manajemen. Kondisi tersebut perlu segera ditemukan penyebabnya dan dicarikan jalan keluar agar ke depan segera dilakukan perbaikan.

Beberapa hal yang masih belum maksimal dilakukan oleh RS Siaga Raya, yaitu terkait dengan memaksimalkan ruangan IGD yang tersedia. RS Siaga Raya belum menyediakan ruangan zona pasien dengan gejala COVID19 dan zona pasien tanpa gejala COVID-19 sehingga beresiko meningkatkan penularan COVID-19 terhadap pasien lain dan tenaga kesehatan yang bertugas.

Hal berikutnya yang dirasa belum maksimal adalah, belum adanya SOP yang jelas 
sehingga pelaksanaan manajemen klinis dilapangan masih berantakan dan hanya mengikuti panduan pada KEMENKES dan WHO. Berdasarkan observasi penulis terlihat untuk triase yang dilakukan masing masing tenaga medis terkadang berbeda satu sama lain. Kondisi ini dapat menghambat berjalannya manajemen klinis yang sesuai dengan Pedoman pencegahan dan pengendalian Coronavirus Disease (COVID-19) Rev.5.

\section{KESIMPULAN DAN SARAN \\ Kesimpulan}

Manajemen klinis di IGD RS Siaga Raya pada masa pandemi COVID 19 sudah melakukan skrining suhu dan saturasi oksigen serta pertanyaan singkat yang mengarah pada COVID-19 dan Pelaksanaan manajemen klinis pada masa pandemi COVID-19 di Rumah Sakit Siaga Raya sudah berjalan namun belum optimal.

\section{Saran}

Bagi RS Siaga Raya diharapkan dapat terus mengembangkan manajemen klinis yang sudah dijalankan, seperti dalam membedakan alur pasien non COVID-19 dan suspect COVID-19 dan juga konsistensi dalam melakukan skrining awal sebelum pasien mulai masuk IGD, membuat SOP manajemen klinis di IGD serta dilakukan evaluasi berkala dan menyediakan fasilitas atau ruangan khusus untuk pasien suspect COVID-19.

Bagi peneliti selanjutnya dalam penilaian manajemen klinis dikomparasikan dengan penelitian manajemen klinis di RS lain dan disertakan informan ahli manajemen klinis.

\section{DAFTAR PUSTAKA}

1. CDC. 2020. Standard Operating Procedure (SOP) for Triage of Suspected COVID-19 Patients. Tersedia pada https://www.cdc.gov/coronavirus/20 19-ncov/hcp/non-us- settings/soptriage-prevent- transmission.html (diakses tanggal 18/1/2021).

2. Direktorat Bina Keperawatan, Departemen Kesehatan RI, Pedoman Pelayanan Keperawatan Gawat Darurat di Rumah Sakit, Jakarta, 2005.

3. Direktorat Bina Pelayanan Penunjang Medik dan Sarana Kesehatan, Kementerian Kesehatan, Pedoman Teknis Bangunan Rumah Sakit Ruang Gawat Darurat, Jakarta, 2012.

4. Direktorat Jenderal Bina Upaya Kesehatan, Kementerian Kesehatan RI, Pedoman Penyelenggaraan Rumah Sakit, Jakarta, 2012.

5. Direktorat Jenderal Bina Upaya Kesehatan, Kementerian Kesehatan RI, Pedoman Penyusunan Standar Pelayanan Minimun di Rumah Sakit, Jakarta, 2012. 
6. Direktorat Jenderal Pelayanan Kesehatan Kementerian Kesehatan RI. 2020. Panduan Teknis Pelayanan Rumah Sakit Pada Masa Adaptasi Kebiasaan Baru. Direktorat Pelayanan Kesehatan Rujukan.

7. Djoko Wijono, M.S, Manajemen Mutu Pelayanan Kesehatan, Volume 1, Airlangga University Press, Surabaya, 2000.

8. Gugus Tugas Percepatan Penanganan Covid-19. 2020. Pedoman Penanganan Cepat Medis dan Kesehatan Masyarakat COVID-19 di Indonesia.

9. Keputusan Menteri Kesehatan No. HK.01.07/MENKES/413/2020

Tentang Pedoman Pencegahan dan Pengendalian CORONAVIRUS DISEASE (COVID-19).

10. Keputusan Menteri Kesehatan RI, Nomor 856 tahun 2009 tentang Standar Instalasi Gawat Darurat RS, Jakarta 2009
11. Kementerian Kesehatan RI, UU Nomor 44 tahun 2009 tentang Rumah Sakit

12. Kementerian Kesehatan RI. 2020. Pedoman Pencegahan dan Pengendalian Coronavirus Disease (COVID-19).

13. Lembaga Administrasi Negara, Modul Pendidikan dan Pelatihan Kepemimpinan Tingkat III ; Teknik -Teknik Analisis Manajemen, LAN, Jakarta, 2008

14. Program Pascasarjana Universitas Respati Indonesia. 2020. Buku Pedoman Tesis.

15. Program Studi Administrasi Rumah Sakit Universitas Respati Indonesia, Modul Operation Research and System Analysis RS (ORSA RS), Jakarta, 2014

16. Song, C. Y., Xu, J., He, J. Q., \& Lu, Y. Q.(2020). COVID-19 early warning score: a multi-parameter screening tool to identify highly suspected patients. Tersedia pada https://www.medrxiv.org/content/10. 1101/2020.03.05.20031906v1 (diakses tanggal 18/1/2021) 